\title{
Across the Indian Ocean: the prehistoric movement of plants and animals
}

\section{Dorian Q Fuller ${ }^{1}$, Nicole Boivin ${ }^{2}$, Tom Hoogervorst ${ }^{2} \&$ Robin Allaby $^{3}$}

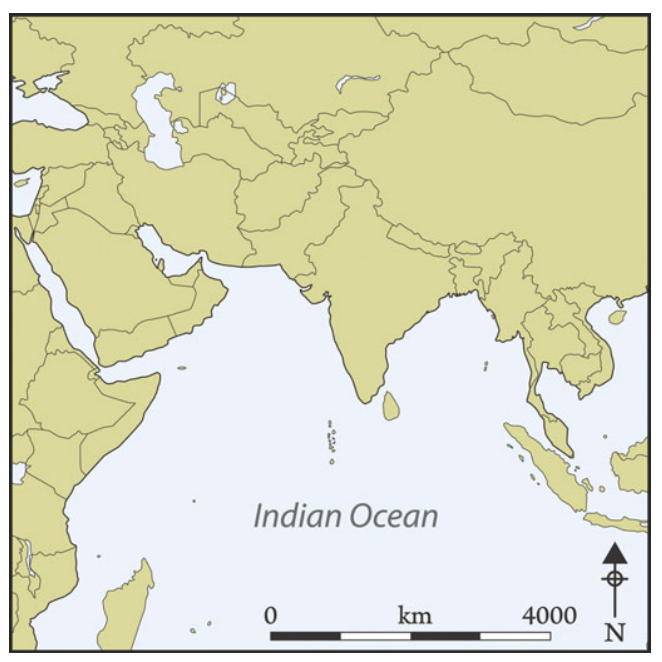

Here is a major research project that is peopling the Indian Ocean with prehistoric seafarers exchanging native crops and stock between Africa and India. Not the least exciting part of the work is the authors' contention that the prime movers of this maritime adventure were not the great empires but a multitude of small-scale entrepreneurs.

Keywords: India, Sri Lanka, Island Southeast Asia, Neolithic, Bronze Age, millet, banana, chicken

\section{Introduction}

The study of prehistory resembles a complex jigsaw and for much of the last half century Peter Bellwood has been at work finding and fitting pieces together, especially as they pertain to the island worlds of the western Pacific. His work has been pre-eminent in generating new understanding and fresh debate about the origins of Austronesian language speakers and the spread of agriculture and languages through Island Southeast Asia and the Pacific (e.g. Bellwood 1987, 1997). Austronesian is the most geographically dispersed of any global

1 Institute of Archaeology, University College London, 31-34 Gordon Square, London WC1H OPY, UK (Email: d.fuller@ucl.ac.uk)

2 School of Archaeology, University of Oxford, New Barnett House, 28 Little Clarendon Street, Oxford OX1 2HU, UK

3 School of Life Sciences, University of Warwick, Wellesbourne, Warwick CV35 9EF, UK

Received: 14 September 2010; Accepted: 17 November 2010; Revised: 13 December 2010

ANTIQUITY 85 (2011): 544-558

http://antiquity.ac.uk/ant/085/ant0850544.htm 
language family in pre-modern times and the inclusion of the Malagasy language in it implies that - complementary to the eastward spread of Austronesian into the Pacific a westward extension of Austronesian speaking seafarers was involved in the peopling of Madagascar.

In this paper we explore the wider Indian Ocean context of this western Austronesian expansion and highlight how current research, including our Sealinks project (see Acknowledgements), is helping to reveal processes of cultural contact, trade and biological translocations in the Indian Ocean in later prehistory, from what can be termed the Bronze Age (in western Asian chronologies) through to the Iron Age and later. This research is inherently interdisciplinary, and thus follows in the footsteps of Peter Bellwood's pioneering archaeology of island cultures.

We also draw upon another strand of Bellwood's work, namely his focus on small-scale societies as major forces of cultural history. The actors in the drama of Austronesian and Polynesian origins, who created new worlds in Island Southeast Asia and the Pacific, and seafaring technologies of unparalleled sophistication, were not the river valley civilisations or literate cities that so often capture the archaeological imagination, and dominate the public image of archaeology. Instead, it was small-scale, village or lineage groups of farmers and seafarers who played the key role in the peopling of the Pacific and the cultural transformation of Neolithic Island Southeast Asia. Similarly, there is mounting evidence that small-scale coastal societies were often the pioneers in creating cross-cultural contacts and translocating plants and animals in the early Indian Ocean (Boivin \& Fuller 2009).

In this paper we sketch the emerging picture of a dynamic prehistoric Indian Ocean, in which links were created between societies in East Africa, Arabia, South Asia and Southeast Asia, all prior to the development of the better documented trade of later periods, including the famous spice trade of the Roman and subsequent eras (Miller 1968; Cappers 2006; Boivin et al. 2009: 268-9). This picture emerges from archaeological evidence, and particularly the evidence of translocated crop plants, as well as from historical linguistics, most notably relating to tree crops and boat technology, with a growing contribution from genetic studies of animals, including domesticated and commensal species.

\section{The Bronze Age inter-savannah translocations (c. 2000-1500 BC): north-east Africa, India, Arabia}

The connections between Africa and India, which constitute the first act of the narrative of transoceanic connections in the north-western part of Indian Ocean (Figure 1), took place as the hitherto separate trading spheres of the Persian/Arabian Gulf and the Red Sea/Gulf of Aden became interlinked, probably at the end of the third millennium BC. Trade and contact in the southern part of the Red Sea began as early as the Neolithic, as indicated by the movement of obsidian from Ethiopia to Yemen (Khalidi 2009), and from the fourth millennium BC stretched northward to Egypt as well, when incense and other goods were no doubt also part of the increasing flow of commodities across the region (Boivin \& Fuller 2009). The much later expeditions of the Egyptian state southwards towards Punt, in search of incense and other exotica, were likely built on these earlier Neolithic contacts, which began in an era prior to local cereal agriculture, in which settlements 


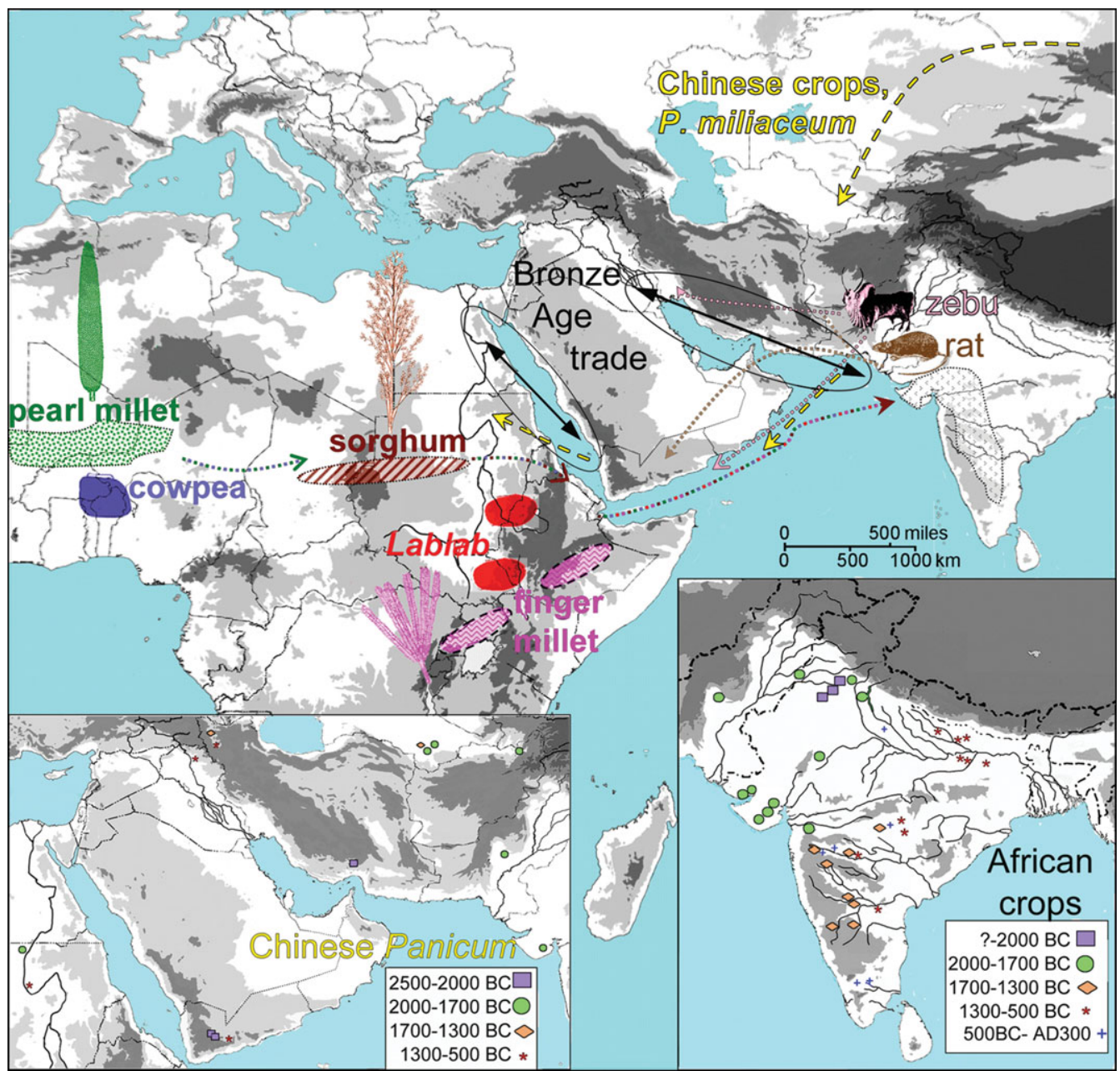

Figure 1. Schematic map of major Bronze Age translocations between South Asia, Arabia and Africa (after Fuller \& Boivin 2009). Inset lower left: map of the distribution of archaeobotanical evidence of broomcorn millet (Panicum miliaceum) of Chinese origin, suggesting dispersal from South Asia to Arabia and Nubia via the sea. Inset lower right: map of the distribution of sites in South Asia with archaeobotanical evidence for one or more crops of African origin.

are still mainly dominated by early to mid Holocene shell middens. From c. 2000 BC, elements of the Red Sea/Gulf of Aden sphere appear to have been brought within the remit of an extended India-Gulf trading network, presumably through the activities of the coastal societies of southern Arabia and/or the agency of Gujarati seafarers, as well as the involvement of an undetermined source in Africa. Five African crops (Figure 1) reached South Asia shortly thereafter (Boivin \& Fuller 2009: 155-60; Fuller \& Boivin 2009).

It has been known for many years that some of the major crops of the drier regions of India, such as sorghum (Sorghum bicolor), pearl millet (Pennisetum glaucum) and finger millet (Eleusine coracana), originated in Africa and arrived in India at some point in prehistory 
(e.g. Possehl 1986; Fuller 2003). A popular argument has been that these crops arrived in the Harappan urban period (2600-2000 BC), brought by Harappan 'seafarers' (e.g. Possehl 1997), but there is little firm evidence to support this. Recent re-assessments, of both botanical identifications and archaeological context (Fuller \& Madella 2001; Fuller 2003), leave reason to doubt the few grains reported from the Harappan urban period; in contrast, there is now a large accumulation of evidence for these crops in India from the second millennium BC, including finds from 33 sites (Figure 1, right inset). What the dating evidence currently suggests is that this transfer of African crops took place at the end of the Harappan era, perhaps as the urban Harappan civilisation was undergoing its transformative de-urbanisation process (see Ratnagar 2000; Madella \& Fuller 2006). Given the lack of any other material evidence for Harappan or South Asian contacts with the Red Sea or Africa before $2000 \mathrm{BC}$, we have argued that this transfer took place primarily between north-east Africa and/or Yemen and western India, probably outside of the context of the Bronze Age trade between major civilisations (Boivin \& Fuller 2009). It is, of course, well documented that the Harappan civilisation was involved in maritime trade with Oman, Bahrain and Mesopotamia in the second half of the third millennium BC (e.g. Ratnagar 1994; Ray 2003: 84-99). But this trade was between urban actors, and increasingly appears to have been built on earlier regional contacts between small-scale coastal fishing and agropastoral societies.

Moving in the other direction was the Asian broomcorn millet (Panicum miliaceum), ultimately of Chinese origin, which had left China on westward trade routes by c. 2200 BC (Frachetti et al. 2010). Broomcorn millet is known from other central Asian sites from around $2000 \mathrm{BC}$ and is found in Pakistan at c. $1900 \mathrm{BC}$, Yemen at around 2000 BC, and in Sudanese Nubia by c. 1700 BC (Figure 1, left inset), while being absent from intervening regions such as Egypt and Mesopotamia (Fuller \& Boivin 2009). Zebu cattle may also have moved from India to Yemen and East Africa starting at this time, although this was presumably the first stage in an ongoing process of gene flow through introduced bulls which made the genetic landscape of south Arabian and African cattle one of hybridity between African taurine and Indian zebu stocks, with evidence for interbreeding most marked at the margins of the Indian Ocean (Hanotte et al. 2002; Ibeagha-Awemu et al. 2004). These zebu-hybrid cattle played an important role in the longterm success and southernmost spread of cattle pastoralists in eastern Africa (cf. Marshall 1989).

The Arabian Sea corridor, which led to early species exchange between the savannahs of Africa and India, was in some ways a precursor to the later pepper route of the spice trade (cf. Miller 1968; Cappers 2006; Boivin et al. 2009). The first hint of this spice trade comes from the findings of valued black peppercorns that were used to fragrance the nostrils of the deceased Pharaoh Ramses II (c. 1200 BC) (Plu 1985). This spice is endemic only to the wet forests of southern India (Asouti \& Fuller 2008: 47), and in all likelihood was supplied by hunter-gatherer groups to coastal groups (Morrison 2002). At this date it is unclear whether any farming was practiced along the coastal plains of southern India, with rice agriculture in the far south of India normally dated after 1000 BC (Fuller et al. 2010), and it may be the case that the earliest pepper was moved between coastal hunter-fisher groups into the emerging network of Arabian Sea voyaging and exchange. 


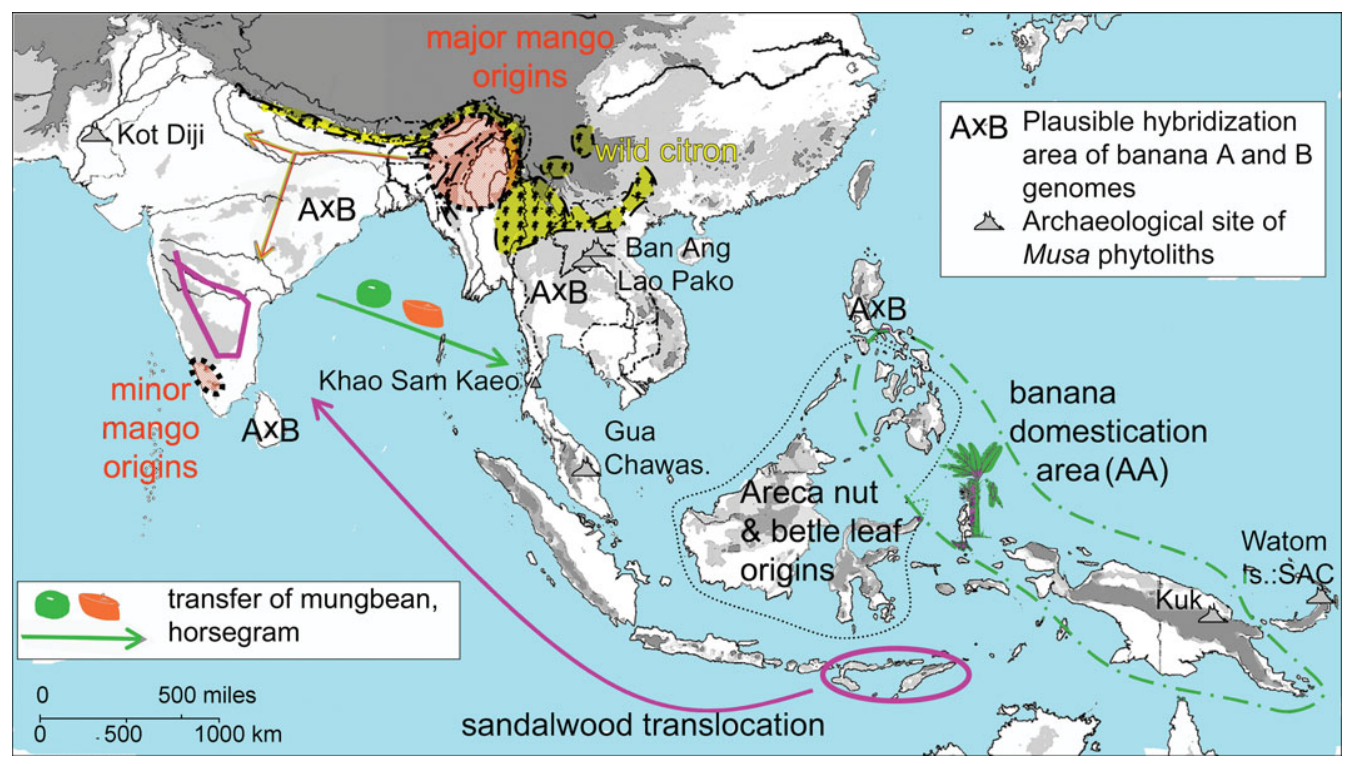

Figure 2. Map summarising major prehistoric translocations of economic plants between Southeast Asia and South Asia, as discussed in the text. Archaeological sites with banana phytoliths are indicated (based on reviews of Lentfer 2009; Fuller \& Madella 2009). Probable wild distributions of some taxa are indicated based on a best guess of the first author, drawing upon a range of botanical sources.

\section{The Bay of Bengal metal age corridor: trees from the Malay Peninsula and westwards to peninsular India}

If the lesson of Arabian trade is that Bronze Age states and civilisations in the region intensified trade on the foundations of earlier contacts amongst small-scale societies, then we might look for a similar pattern in the eastern Indian Ocean, in the Bay of Bengal (Figure 2). Evidence for regular trade between India and the Malay Peninsula in the form of Indian-style stone beads and ceramics (Northern Black Polished Ware) is extensive for the later part of the first millennium BC (Bellina \& Glover 2004), and predates the IndoRoman trade era. Iron Age trade is well documented from recent excavations at the urban site of Khao Sam Kaeo in southern Thailand (on the Malay Peninsula) occupied from $c$. 400 BC (Bellina-Pryce \& Silapanth 2008). Indeed, it is suggested that Indian craftsmen had set up shop at Khao Sam Kaeo, based on apparently locally manufactured stone beads and pottery that resembled the technology and operational sequences of those known to be made in India. Crop evidence from this site also indicates the presence of Indian domesticates, especially some of the classic pulses for making dal dishes in peninsular India, including mungbean (Vigna radiata) and horsegram (Macrotyloma uniflorum), both of which had their origins in south India (Castillo \& Fuller 2010). By this period of the later first millennium BC, we are dealing with large urban sites in both India and the Malay Peninsula. So the question arises: is there evidence that this inter-urban long-distance trade was based on the earlier agency of small-scale societies around the coasts of the Bay of Bengal? 
The evidence we have comes from a combination of biogeographical, historical linguistic sources and just a dash of hard archaeobotanical evidence. A number of important cultivars in south India, especially amongst trees, have their likely wild origins in Southeast Asia (Figure 2). These include the Areca-nut palm, the nuts of which are chewed as a stimulant together with slaked lime and the leaves of the vine Piper betle. Both are probably from Island Southeast Asia (see e.g. Zumbroich 2007). Other Southeast Asian tree crops may have come to south India via lands to the north, as they have probable origins in north-east India or northern Southeast Asia, around the Assam/Burma/Yunnan area westwards to the eastern Himalayan foothills; these include Citrus medica (the citron, precursor of the lemon) and most domesticated mangos (Mangifera indica) (see Asouti \& Fuller 2008: 91, 114-15).

In linguistic terms, all of these species date to the same stratum of Dravidian languages, with reconstructible etyma in Proto-South Dravidian, at the same level as textile-related terminology (Fuller 2008), crops of African origins and metallurgical terms, especially for gold and copper (Fuller 2007; also Southworth 2005). In south India, the earliest finds of African domesticates (1600-1500 BC), metal objects and frequent spindle whorls (both c. $1500 \mathrm{BC}$ ) suggest a minimal age for this proto-language. Archaeological wood charcoal from the Neolithic site of Sanganakallu (Sannarachamma) in south India has produced a few specimens of probable mango, from levels dating to 1400-1300 BC, with probable Citrus as well, which confirms the adoption of these Southeast Asian arboriculture species prior to the Iron Age (Asouti \& Fuller 2008: 134).

Another interesting tree that appears to have come to south India from the east at this time is the true sandalwood (Santalum album). Sandalwood is probably originally wild in the driest parts of Indonesia, such as eastern Java and the Lesser Sundas, where its distribution appears natural on account of being adjacent to its many congeneric relatives of Island Southeast Asia, Australia and the Pacific (Fischer 1938; Burkill 1966: 1987; Asouti \& Fuller 2008: 116-17; Harbaugh \& Baldwin 2008). Wood charcoal from the latest Neolithic levels of Sanganakallu (Sannarachamma) in south India, identified as Santalum, however, places it in the southern Deccan by c. 1300 BC (Asouti \& Fuller 2008: 135), and this argues for a human-mediated translocation by this time.

\section{An Iron Age southern tropics pairing (from c. $500 \mathrm{BC}$ ): from South/Southeast Asia to Africa}

The banana is another crop-plant that comes from the east, with recent research favouring initial domestication in New Guinea, but probably with additional input of varieties from the Philippines (e.g. Donohoe \& Denham 2009; Kennedy 2009). In South Asia, wild bananas and their relatives are few, and their distributions are limited, mainly to the wetter rainforests and moist deciduous hill forests (Fuller \& Madella 2009).

Archaeological recovery of bananas usually relies on identification of phytoliths (Mbida et al. 2006), and these are so far absent from the few phytolith studies conducted in India (Fuller \& Madella 2009). However, banana phytoliths from the Harappan site of Kot Diji in southern Pakistan (Fuller \& Madella 2009) could indicate a westward diffusion of bananas by sea from Island Southeast Asia to the Indus as early as 2000 BC (Figure 2). Further evidence is needed, however, to rule out the possibility that these phytoliths derived from 


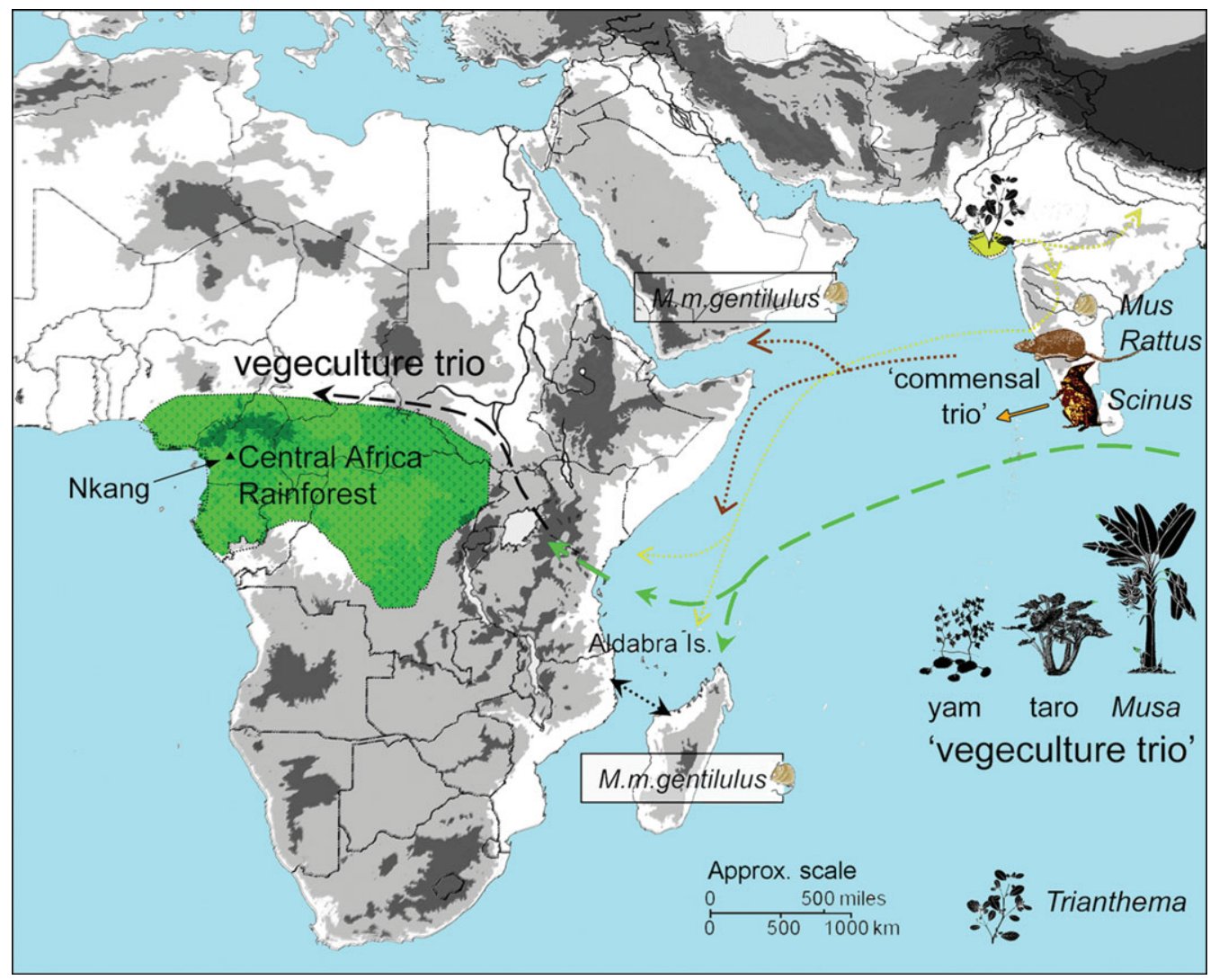

Figure 3. Schematic map of major translocations from Asia to Africa including commensals, the weed horse purslane (Trianthema) and the Asian vegecultural trio.

another Musa grown as a raw material source (for fibre or paper) or even a garden ornamental (Fuller \& Madella 2009). There are additional reports of archaeological Musa phytoliths from mainland Southeast Asia and New Guinea (see Lentfer 2009), although the use of some local wild form of Musa cannot be ruled out.

It is clear, however, that bananas (or plantains) (Musa paradisiaca), are entirely introduced to Africa, as were the greater yam (Dioscorea alata) and taro (Colocasia esculenta). All three Asian taxa are found traditionally across the African continent, but their absence from intervening areas like northern India and Arabia makes Murdoch's (1959: 222) hypothesis of a coastal route of transfer problematic, and instead points to a central Indian Ocean corridor (Figure 3). Recent archaeobotanical evidence, however, in the form of phytoliths in Iron Age pits in Cameroon, imply that bananas had arrived and reached western Africa prior to the colonisation of Madagasascar, perhaps by c. $500 \mathrm{BC}$ (Mbida et al. 2006). Claims for earlier bananas in Uganda, at Munsa (Lejju et al. 2006), are more dubious, due especially to stratigraphic dating issues but also due to questions about preserved morphology (Neumann \& Hildebrand 2009). 
De Langhe (2007) has made a fairly convincing case for a trans-African dispersal route for the banana, from the East African coast, through the forest patches of Usambara and Pare and along the northern fringe of the equatorial rainforest, into West Africa, from where plantains are argued to have possibly 'fueled' the Bantu expansion. Blench (2009) has meanwhile proposed a more daring continental circumnavigation hypothesis, based on the lack of evidence for ancient plantain cultivation in East Africa, the problems of a dispersal route through the intervening dry regions between the coast and central African rainforest, and the known sailing capabilities of the Austronesians. One way to distinguish between these possible scenarios would be to use genetics to determine which populations are most likely to be associated with the founding point of these species on the African continent.

Like bananas, chickens are a staple food source of traditional African villages, but nevertheless, have their origins in the red junglefowl (Gallus gallus), which is native from sub-Himalayan northern India through southern China and Southeast Asia. Across this area, chickens were probably brought into domestication more than once, as suggested by genetic data, although good zooarchaeological data remains scarce (see Fuller 2007: 400401; Kanginakudru et al. 2008; Berthouly-Salazar et al. 2010). While some chickens may have first entered Africa overland, moving up the Nile from Egypt to Nubia, historical linguistic data suggest perhaps three separate introductions, including two from the north across the Sahara, and one from the Indian Ocean and the east coast of Africa (Williamson 2000). As with taro and bananas, chickens appear to be deeply culturally embedded in West and Central African subsistence, suggesting considerable time-depth to their presence, although this is not yet supported by archaeozoology (Williamson 2000; cf. MacDonald 2000). Unfortunately, difficulties with accurately identifying chicken bones from indigenous gallinaceous birds (ses MacDonald 1992) mean that reliable archaeology for African chickens is still limited.

While southern India is the native home to the unrelated wild grey junglefowl (Gallus sonneratii) and Sri Lanka boasts its own jungle fowl (Gallus lafayetii), both regions played a role in shaping the diversity of chickens. For Sri Lanka, this is indicated in the large number of chicken genetic lines (haplogroups) found there, which imply multiple introductions from India, mainland Southeast Asia and Malaysian Borneo (Berthouly-Salazar et al. 2010), whereas peninsular India's grey junglefowl appears to have provided a key gene found in many modern chickens, namely the gene for yellow legs, which are indeed distinct from the red legs of wild red junglefowl, and white and black-legged chickens (Eriksson et al. 2008). This attests to the importance of intercultural contacts and exchanges around the margins of the Indian Ocean in creating some of the agricultural biodiversity that we take for granted today.

While domesticated crops would have been carried and then propagated intentionally, many more species have been moved by mistake, including commensal animals and agricultural weeds (Figure 3). Elsewhere (Fuller \& Boivin 2009) we have reviewed evidence for a few potential weeds that have been translocated from Africa to Asia or Asia to Africa, apparently via the Indian Ocean based on their absence from the flora of intervening land regions (Egypt, Mesopotamia, Iran). In general we know less about weeds than about crops, but to take one example, we consider the horse purslane (Trianthema portulacastrum), a frequent weed in Gujarat from Harappan and Late Harappan sites, presumably of millet 
fields (Weber 1991; Reddy 1994), to be a subject of anthropogenic dispersal. It was present in the Ganges basin from the Chalcolithic period (after $1400 \mathrm{BC}$ ), probably infesting dry rice fields (Fuller \& Qin 2009: tab. 2), and in south India by early historic times (c. 300 BC), at Paithan on the Godavari River in Maharashtra (Fuller, unpublished). Subsequent eastward spread is indicated by the occurrence today in dry rice fields in mainland Southeast Asia (Noda et al. 1985). At some stage, as yet undated, both Trianthema species came to the millet and sorghum fields of the African savannahs, where they persist as weeds to the present day.

Commensal animals are rather better studied than weeds, as the products of anthropogenic dispersal. Genetic studies of rats in Madagascar and the islands of the western Indian Ocean point to origins in India, probably via Arabia or the Middle East (Hingston et al. 2005; Tollenaere et al. 2010). The house mouse (Mus musculus) is also regarded as Indian in origin (Boursot et al. 1993), although its presence in the Epipalaeolithic (Natufian) of the Near East implies that it dispersed in the absence of human sedentism and perhaps only evolved as a commensal later with the development of Near Eastern agriculture (Auffray et al. 1990); when commensal mice first occurred in South Asia is unknown. Nevertheless, the mouse forms found on Madagascar are a genetically distinctive subspecies found otherwise in Yemen (Mus musculus ssp. gentilus), implying movement southwards from Yemen after an introduction to there from India (Duplantier et al. 2002). Finally, the Asian house shrew (Suncus murinus), is also a ship-borne invasive species that originated in South Asia (Yamagata et al. 1995; Kurachi et al. 2007). The high morphological variability of this species in East Africa and the Arabia Peninsula suggests multiple introductions directly from South Asia and from early differentiated types of Southeast Asia (Hutterer \& Tranier 1990). Whether these commensals were stowaways on boats or potential protein snacks for long voyages is unknown, but future zooarchaeology needs to target the recovery and careful identification of micro-fauna to pin down the cultural context of their dispersal around the Indian Ocean.

\section{Maritime technology}

It has long been recognised that the Austronesian tradition of Island Southeast Asia involved the sequential development and refinement of sail-boat technology, as single and doubleoutrigger canoes with sails rigged in the direction of the ship's longitudinal axis made sailing against the wind increasingly efficient (e.g. Doran 1981: 93; Mahdi 1999: 145). The distribution of Southeast Asian sail types, methods of plank-fastening and single or double outriggers around the coasts of India, Sri Lanka, East and south-eastern Africa suggests the introduction of boat-building techniques from Island Southeast Asia (Figure 4). This impression is reinforced by the presence of a small number of Austronesian terms relating to boats and parts of boats that are found in South Asian languages such as in Hindi, Tamil, Sinhalese (Sri Lanka), Dhivehi (Maldive Islands) and possibly the languages of the Andamanese islanders. Subsequently, contact between sailors and boat-builders from different backgrounds intensified, and at least since Islamic times we can observe many more examples of Indian Ocean maritime vocabulary transgressing linguistic boundaries. It may be argued, based on our still limited knowledge of nautical terminology in Arabic, Farsi, 


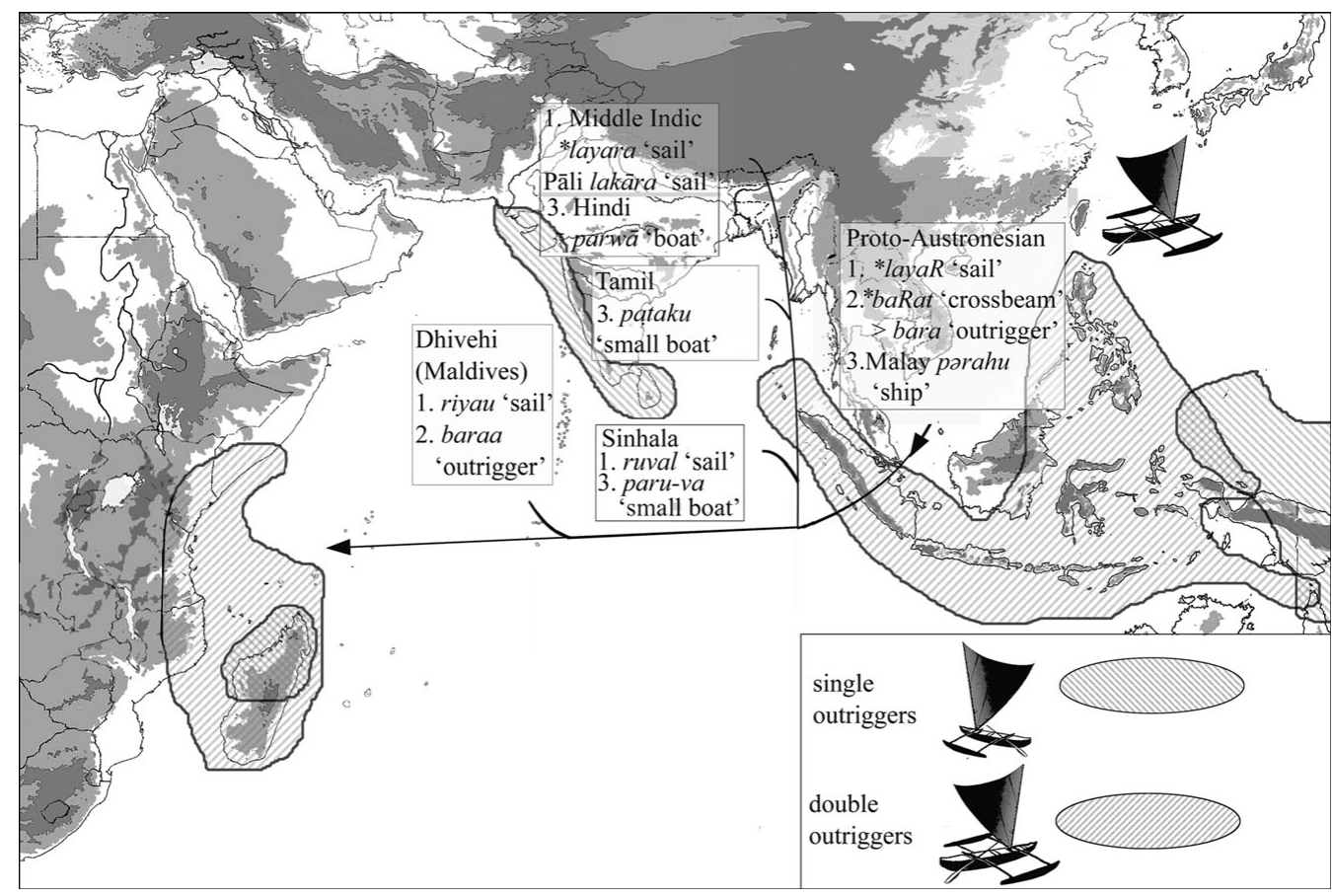

Figure 4. Map showing the general distribution of nautical related loanwords of inferred Austronesian linguistic origins in South Asia and the Indian Ocean. This is depicted over the ethnographic/historical distribution of single and double outrigger sailing canoes, believed to originate as a technology in Island Southeast Asia.

Swahili, Hindi, Malay and other languages (cf. Glidden 1942; Johnstone \& Muir 1964; Prins 1970; Liebner 1993; Mohebbi 1996), that several individual languages contributed to and became part of a shared Indian Ocean seafarers' lexicon, built on the foundations of inter-ethnic trade networks that emerged many centuries before.

On the other hand, looking at maritime vocabulary has its pitfalls too, as many languages prefer a native word, often of descriptive nature, over a loanword, even if the item concerned is the result of foreign introduction. Illustratively, most words for 'outrigger' in South Asia and East Africa are not clearly derived from any Austronesian source, whereas all stages of development point towards an insular Southeast Asian origin of the device, and militate against independent invention in South Asia and/or East Africa. Again, this urges us to move beyond the constraints of one specific scholarly discipline towards the incorporation of other fields.

\section{Conclusions}

In the jigsaw puzzle of Indian Ocean prehistory, we still have only scattered interdisciplinary puzzle pieces, and are very far from a complete or even near complete picture. Nevertheless, those pieces of the puzzle that do fit together suggest patterns of inter-regional linkage that we can broadly constrain in time and space. We can identify a northwestern Indian Ocean (Arabian Sea) zone that gradually enabled contacts between savannah-oriented agricultural 
societies in India and Africa, starting about 2000 BC (and perhaps some centuries earlier). African cereals slotted easily into the existing subsistence regimes that were already established in monsoonal India, while zebu cattle added important genetic traits to African cattle.

The emergence of this corridor of exchange was followed by later eastward linkages between South Asia and Southeast Asia. One challenge for agricultural translocations across the Bay of Bengal was that the dry tropical woodlands and savannahs that dominate much of peninsular India are poorly matched with the wet tropical forests of Southeast Asia. Translocations would have required a broadening of ecological tolerance, or extra efforts in terms of cultural practice. This probably means that those South Asian regions ecologically most similar to Southeast Asia, such as Orissa (the north-east peninsula) and Sri Lanka, would have played important roles in the initial adoption and adaptation of Southeast Asian cultivars to South Asia.

Does the extra effort involved in translocating these species suggest that contacts were becoming more systematic and closer to what we conventionally think of as trade? In light of the degree of complexity seen emerging in south India and Sri Lanka at this time, and the complex agricultural practices necessary for cultivating tree and vine crops, this is a distinct possibility. Nonetheless, the agency of small-scale seafaring societies at the margins of such emerging polities likely accounts for the actual sea-movements.

Later still, in the first millennium BC, the Indian Ocean actually began to open up in the broad sense. By Iron Age times, systematic trade between urban systems was taking place across the Bay of Bengal and between India and the Red Sea. This period also potentially provides the first evidence for Asian species introduction into the moist tropics of Africa. While this claim still rests heavily on the banana phytoliths from Nkang in Cameroon, other lines of evidence, from plant and animal genetics, and linguistics, suggest that the later centuries BC were a period of increasing flows across the Indian Ocean, mainly it appears, at least from a species point of view, from east to west. The insular Southeast Asian involvement in this is certainly clear for the period of the Malagasy peopling of Madagascar sometime in the first millennium $\mathrm{AD}$, but there is a likelihood that this was only the latest of a series of such movements.

Equally enigmatic are the economic, social, political or cosmological factors that may have played a role in driving seafarers with little more than basic seafaring technology to take on voyages that even in today's world appear to be exceptionally dangerous and even foolhardy. Of course the patterns of monsoon winds, trade winds and ocean currents around the Indian Ocean between summer and winter made these long-distance voyages technically feasible (Pearson 2003), but knowledge of these patterns, adequate food supplies, and the motivations for long return voyages were also necessary. Recognition of the value of exotic domesticated species amongst early farmers (Hayden 2009) may be important in understanding some of these early movements. A parallel may be suggested with the westward movement of broomcorn millet from China, which appears to have been associated with its ritual value amongst steppe pastoralists (Frachetti et al. 2010). What imported artworks and antiquities are today, and spices were in the Classical and medieval periods, exotic crops and animals mostly likely also were in deeper antiquity: luxury items conferring social or religious prestige and evidence of power. But this explanation is probably not enough to explain all contact, and perhaps in particular the more long-ranging. 
We may usefully draw upon Mary Helms' ideas about the notions of power and the exotic that in traditional societies became attached to knowledge and things that came from geographically distant locales (Helms 1988). Indeed, such power could also come to be linked to individuals themselves, suggesting that psychologically-inspired tendencies to wanderlust and adventure also have clear social elements. Whatever the driving factors, it is likely that small-scale maritime societies themselves were also transformed by the contacts in which they engaged (Arnold 1995). And through the early activities of these small-scale societies came wider social and economic transformations. These included the transfer of words, languages, ideas and technologies, the translocation of species with both positive and negative consequences for future generations, and the alteration of the very genetic make-up of people, plants and animals all around the Indian Ocean.

\section{Acknowledgements}

The Sealinks Project based at the University of Oxford is supported by a European Research Council grant to Nicole Boivin, while plant genetic research is being carried out at University of Warwick and archaeobotanical research is focused at the Institute of Archaeology, University College London.

\section{References}

ARNOLD, J.E. 1995. Transportation innovation and social complexity among maritime hunter-gatherer communities. American Anthropologist 97(4): 733-47.

AsoutI, E. \& D.Q. Fuller 2008. Trees and woodlands of South India. Archaeological perspectives. Walnut Creek (CA): Left Coast Press.

Auffray J.-C., F. Vanlerberghe \& J. BrittonDAVIDIAN. 1990. The house mouse progression in Eurasia: a palaeontological and archaeozoological approach. Biological Journal of the Linnean Society 41: 13-25.

Bellina, B. \& I. Glover. 2004. The archaeology of early contact with India and the Mediterranean world, from the fourth century BC to the fourth century AD, in I. Glover \& P. Bellwood (ed.) Southeast Asia: from prehistory to history: 68-88. London: Routledge Curzon.

Bellina-Pryce, B. \& P. Silapanth 2008. Weaving cultural identities on trans-Asiatic networks: Upper Thai-Malay Peninsula - an early socio-political landscape. Bulletin de l'Ecole Française d'Extrême-Orient 93: 257-93.

Bellwood, P. 1987. The Polynesians. Prehistory of an island people. London: Thames \& Hudson.

- 1997. Prehistory of the Indo-Malaysian Archipelago. Honolulu (HI): University of Hawai' $i$ Press.

Berthouly-Salazar, C., X. Rognon, T. Nhu Van, M. Gély, C. Vu Chi, M. Tixier-Boichard, B. Bed'hom, N. Bruneau, E. Verrier, J.C. MaIllard \& J.R. MichauX. 2010. Vietnamese chickens: a gate towards Asian genetic diversity. BMC Genetics 11: 53.
BLENCH, R.M. 2009. Bananas and plantains in Africa: re-interpreting the linguistic evidence. Ethnobotanical Research and Applications 7: 363-80.

BoIVIN, N.L. \& D.Q. Fuller. 2009. Shell middens, ships and seeds: exploring coastal subsistence, maritime trade and the dispersal of domesticates in and around the ancient Arabian Peninsula. Journal of World Prehistory 22: 113-80.

Boivin, N., R. BlenCH, \& D.Q. Fuller. 2009. Archaeological, linguistic and historical sources on ancient seafaring: a multidisciplinary approach to the study of early maritime contact and exchange in the Arabian Peninsula, in M.D. Petraglia \& J.I. Rose (ed.) The evolution of human populations in Arabia. Paleoenvironments, prehistory and genetics: 251-78. Dordrecht: Springer.

Boursot, P., J.-C.AufFray, J. Britton-DaVidian \& F. Bonhomme. 1993. The evolution of house mice. Annual Review of Ecology and Systematics 24: 119-52.

BURKILL, I.H. 1966. A dictionary of the economic products of the Malay Peninsula. Kuala Lampur: Ministry of Agriculture and Cooperatives.

CAPPERS, R. 2006. Roman foodprints at Berenike. Los Angeles (CA): Costen Institute of Archaeology.

Castillo, C. \& D.Q. Fuller. 2010. Still too fragmentary and dependent upon chance? Advances in the study of early Southeast Asian archaeobotany, in B. Bellina, E. Bacus, O. Pryce \& J. Wisseman-Christie (ed.) Studies in honour of Ian Glover: 91-111. Bangkok: River Books. 
DE LANGHE, E. 2007. The establishment of traditional plantain cultivation in the African rain forest: a working hypothesis, in T. Denham, J. Iriarte \& L. Vrydaghs (ed.) Rethinking agriculture: archaeological and ethnoarchaeological perspectives: 361-70. Walnut Creek (CA): Left Coast Press.

Donohoe, M. \& T. Denham. 2009. Banana (Musa spp.) domestication in the Asia-Pacific region: linguistics and archaeobotanical perspectives. Ethnobotany Research \& Applications 7: 293-332.

Doran, E. 1981. Wangka. Austronesian canoe origins. College Station (TX): Texas A\&M University Press.

Duplantier, J.-M., A. Orth, J. Catalan \& F. BONHOMME. 2002. Evidence for a mitochondrial lineage originating from the Arabian Peninsula in the Madagascar house mouse (Mus musculus). Heredity 89: 154-8.

EriksSON, J., G. Larson, U. GunNarsson, B. BED'HOM, M. TIXIER-BOICHARD, L. STRÖMSTEDT, D. Wright, A. Jungerius, A. VereijKen, E. RANDi, P. JENSEN \& L. ANDERSSON. 2008. Identification of the Yellow Skin gene reveals a hybrid origin of the domestic Chicken. PLoS Genetics 4(2): e1000010.

FISCHER, C.E.C. 1938. Where did the sandalwood tree (Santalum album Linn.) evolve? Journal of the Bombay Natural History Society 40: 458-66.

Frachetti, M.D., R.N. Spengler, G.J. Fritz \& A.N. MAR'YASHEV. 2010. Earliest direct evidence for broomcorn millet and wheat in the Central Eurasia steppe region. Antiquity 84: 993-1010.

Fuller, D.Q. 2003. African crops in prehistoric South Asia: a critical review, in K. Neumann, A. Butler \& S. Kahlheber (ed.) Food, fuel and fields. Progress in African archaeobotany (Africa Praehistorica 15): 239-71. Cologne: Heinrich-Barth Institut.

- 2007. Non-human genetics, agricultural origins and historical linguistics, in M. Petraglia \& B. Allchin (ed.) The evolution and history of human populations in South Asia: interdisciplinary Studies in archaeology, biological anthropology, linguistics and genetics: 389-439. Dordrecht: Springer.

-2008. The spread of textile production and textile crops in India beyond the Harappan zone: an aspect of the emergence of craft specialization and systematic trade, in T. Osada \& A. Uesugi (ed.) Linguistics, archaeology and the human past (Indus Project Occasional Paper 3): 1-26. Kyoto: Indus Project, Research Institute for Humanity and Nature.

FulLeR, D.Q. \& N.L. BoIVIN. 2009. Crops, cattle and commensals across the Indian Ocean: current and potential archaeobiological evidence. Etudes Ocean Indien 42/43: 13-46.
Fuller, D.Q. \& M. Madella. 2001. Issues in Harappan archaeobotany: retrospect and prospect, in S. Settar \& R. Korisettar (ed.) Protohistory: archaeology of the Harappan civilization: 317-90. New Delhi: Manohar.

- 2009. Banana cultivation in South Asia and East Asia: a review of the evidence from archaeology and linguistics. Ethnobotany Research \& Applications 7: 333-51.

Fuller, D.Q. \& L. QIN. 2009. Water management and labour in the origins and dispersal of Asian rice. World Archaeology 41(1): 88-111.

Fuller, D.Q., Y.-I. Sato, C. Castillo, L. Qin, A.R. WeissKopf, E.J. Kingwell-Banham, J. SONG, S.-M. Ahn \& J. VAn EtTEN. 2010. Consilience of genetics and archaeobotany in the entangled history of rice. Archaeological and Anthropological Sciences 2: $115-31$.

GLIDDEN, H.W. 1942. A comparative study of the Arabic nautical vocabulary from Al-'Aqabah, Transjordan. Journal of the American Oriental Society 62(1): 68-72.

Hanotte, O., D.G. Bradley, J.W. Ochieng, Y. VerjeE, E.W. Hill \& J.E.O. Rege. 2002. African pastoralism: genetic imprints of origins and migrations. Science 296: 336-9.

Harbaugh, D.T. \& B.G. Baldwin. 2008. Phylogeny and biogeography of the sandalwoods (Santalum, Santalaceae): repeated dispersals throughout the Pacific. American Journal of Botany 94: 1028-40.

HaYden, B. 2009. The proof is in the pudding: feasting and the origins of domestication. Current Anthropology 50(5): 597-601.

Helms, M.W. 1988. Ulysses' sail: an ethnographic odyssey of power, knowledge, and geographical distance. Princeton (NJ): Princeton University Press.

Hingston, M., S.M. GoOdman, J.U. GanZHORn \& S. SOMMER. 2005. Reconstruction of the colonization of southern Madagascar by introduced Rattus rattus. Journal of Biogeography 32: 1549-59.

Hutterer, R. \& M. Tranier. 1990. The immigration of the Asian house shrew (Suncus murinus) into Africa and Madagascar: vertebrates in the tropics, in G. Peters \& R. Hutterer (ed.) Proceedings of the International Symposium on Vertebrate Biogeography and Systematics in the Tropics: 309-319. Bonn: Zoologisches Forschungsinstitut und Museum Alexander Koenig.

IBEAGHA-AwEMU, E.M., C.O. JanN, C. WEIMANN \& G. ERHARDT. 2004. Genetic diversity, introgression and relationships among West/Central African cattle breeds. Genetics Selection Evolution 36: 637-90. 
Johnstone, T.M. \& J. Muir. 1964. Some nautical terms in the Kuwaiti dialect of Arabic. Bulletin of the School of Oriental and African Studies 27(2): 299-332.

Kanginakudru, S., M. MetTa, R.D. JaKati \& J. NAGARAJU. 2008. Genetic evidence from Indian red jungle fowl corroborates multiple domestication of modern day chicken. BMC Evolutionary Biology 8: 174.

KenNeDY, J. 2009. Bananas: towards a revised prehistory, in A. Fairbairn \& E. Weiss (ed.) From foragers to farmers. Papers in honour of Gordon $C$. Hillman: 190-204. Oxford: Oxbow.

KHALIDI, L. 2009. Holocene obsidian exchange in the Red Sea region, in M. Petraglia \& J. Rose (ed.) The evolution of human populations in Arabia: 279-91. Dordrecht: Springer.

Kurachi, M., B.-L. ChaU, V.-B. Dang, T. DorJi, Y. YAMAMOTO, M. M. NYUNT, Y. MAEDA, L. ChHum-Phith, Namikawa \& T. Yamagata 2007. Population structure of wild musk shrews (Suncus murinus) in Asia based on mitochondrial DNA variation, with research in Cambodia and Bhutan. Biochemical Genetics 45(3/4): 165-83.

LejJu, B.J., P. Robertshaw \& D. Taylor. 2006. Africa's earliest bananas? Journal of Archaeological Science 33: 102-113.

LENTFER, C. 2009. Tracing domestication and cultivation of bananas from phytoliths: an update from Papua New Guinea. Ethnobotany Research and Applications 7: 247-70.

LIEBNER, H. 1993. Remarks on the terminology of boatbuilding and seamanship in some languages of southern Sulawesi. Indonesia and the Malay World 21(59/60): 18-44.

MaCDONALD, K. 1992. The domestic chicken (Gallus gallus) in Sub-Saharan Africa: a background to its introduction and its osteological differentiation from indigenous fowls (Numidinae and Francolinus sp.). Journal of Archaeological Science 19: 303-318.

-2000 . The origins and development of domesticated animals in arid West Africa, in R. Blench \& K. MacDonald (ed.) The origins and development of African livestock: archaeology, genetics, linguistics and ethnography: 127-62. London: UCL Press.

Madella, M. \& D.Q. Fuller 2006. Palaeoecology and the Harappan civilisation of South Asia: a reconsideration. Quaternary Science Reviews 25: 1283-1301.

MAHDI, W. 1999. The dispersal of Austronesian boat forms in the Indian Ocean, in R. Blench \& M. Spriggs (ed.) Archaeology and language III. Artefacts, languages and texts: 144-79. London: Routledge.

Marshall, F. 1989. Rethinking the role of Bos indicus in Sub-Saharan Africa. Current Anthropology 30: 235-40.
Mbida, Ch., E. De Langhe, L. VRydaghs, H. Doutrelpont, R. Swennen, W. Van Neer \& P. De Maret. 2006. Phytolith evidence for the early presence of domesticated banana (Musa) in Africa, in M. Zeder, D. Bailer, E. Emshwiller \& B.D. Smith (ed.) Documenting domestication: new genetic and archaeological paradigms: 68-81 Berkeley (CA): University of California Press.

Miller, J.I. 1968. The spice trade of the Roman Empire. Oxford: Oxford University Press.

MohebBi, P. 1996. A Persian nautical glossary from ca. 1900. Iran 34: 129-33.

MORRISON, K. 2002. Pepper in the hills: uplandlowland exchange and the intensification of the spice trade, in K.D. Morrison \& L.L. Junker (ed.) Forager-traders in South and Southeast Asia: 105-128. Cambridge: Cambridge University Press.

Murdoch, G.P. 1959. Africa: its peoples and their culture history. New York: McGraw-Hill

NeumanN, K. \& E. Hildebrand. 2009. Early bananas in Africa: the state of the art. Ethnobotany Research \& Applications 7: 353-62.

Noda, K., M. Teerawatsakul, C. Prakongvongs \& L. ChaiWIRATNUKul 1985. Major weeds in Thailand. Bangkok: Department of Agriculture.

Pearson, M. 2003. The Indian Ocean. London: Routledge.

Plu, A. 1985. Bois et graines, in L. Balout \& C. Roubet (ed.) La momie de Ramse's II. Contribution scientifique à l'égyptologie: 166-74. Paris: Editions Recherches sur les Civilisations.

PosseHL, G.L. 1986. African millets in South Asian prehistory, in J. Jacobson (ed.) Studies in the archaeology of India and Pakistan: 237-56. New Delhi: Oxford \& IBH Publishing Co.

- 1997. The seafaring merchants of Meluhha, in R. Allchin \& B. Allchin (ed.) South Asian archaeology 1995: 87-100. New Delhi: Oxford \& IBH Publishing Co.

PrINS, A.H.J. 1970. A Swahili nautical dictionary. Dar es Salaam: Chuo cha Uchunguzi wa Lugha ya Kiswahili.

Ratnagar, S. 1994. Harappan trade in its 'world context'. Man and Environment 19(1/2): 115-28.

- 2000. The end of the great Harappan tradition. New Delhi: Manohar.

RAY, H.P. 2003. The archaeology of seafaring in ancient South Asia. Cambridge: Cambridge University Press.

REDDY, S.N. 1994. Plant usage and subsistence modeling: an ethnoarchaeological approach to the late Harappan of northwest India (PhD dissertation, University of Wisconsin). Ann Arbor (MI): University Microfilms. 
SOUTHWORTH F. 2005. The linguistic archaeology of South Asia. London: Routledge.

Tollenaere, C., C. Brouat, J.-M. Duplantier, L. Rahalison, S. Rahelinirina, M. Pascal, $\mathrm{H}$. MoOre, G. Mouahid, H. Liers \& J,-F. Cosson 2010. Phylogeography of the introduced species Rattus rattus in the western Indian Ocean, with special emphasis on the colonization history of Madagascar. Journal of Biogeography 37: 398-410.

Weber, S.A. 1991. Plants and Harappan subsistence. An example of stability and change from Rojdi. New Delhi: Oxford \& IBH Publishing Co.

Williamson, K. 2000. Did chickens go west?, in R. Blench \& K. MacDonald (ed.) The origins and development of African livestock: archaeology, genetics, linguistics and ethnography: 368-448. London: UCL Press.
Yamagata, T., K. Ohishi, M.O. Faruque, J.S. MasangKay, C. Ba-Loc, D. Vu-Binh, S.S. MANSJOER, H. IKedA \& T. NAMIKaWA. 1995. Genetic variation and geographic distribution of the mitochondrial DNA in local populations of the musk shrews, Suncus murinus. Japanese Journal of Genetics 70: 321-37.

ZumbrolCH, T.J. 2007. The origin and diffusion of betel chewing: a synthesis of evidence from South Asia, Southeast Asia and beyond. eJournal of Indian Medicine 1: 87-140. 